\title{
COMPARING THE ORIGINS OF EXTERNAL DEFAULT, DOMESTIC DEFAULT AND BANKING CRISIS
}

\author{
Chien-Jung Ting \\ SHU-TE University, Taiwan \\ Ching-Shu Wang \\ SHU-TE University, Taiwan
}

\begin{abstract}
Purpose of this paper is to explore the origins of external default, domestic default and banking crisis. Using Random Forest (Breiman et al.,1984) to measure variable importance, we adopt the long-dated cross-country data on public debt developed by Reinhart and Rogoff (2009), which covers 66 countries in 1970 to 2012. The robust conclusions as follows.1. "Debtrelated variables" have higher importance on eruption of external default. 2. "Macroeconomicrelated variables" reflecting the background of a country have higher importance on eruption of domestic default. 3. "The interest payments from debt" have higher importance on eruption of banking crisis. Especially, the origins of external default are corresponding with those of banking crisis. In the past, the relationship between macroeconomic variables and debt default is hard to conclude. However, we get robust conclusions, reflecting that "macroeconomicrelated variables", "debt-related variables" are indeed important origins of external default, domestic default and banking crisis.
\end{abstract}

Keywords: External default, Domestic default, Probit model, Random Forest

JEL codes: E50, E60, F33, F34

\section{Introduction}

We aim at the origins of external default, domestic default and banking crisis. The components of sovereign default crisis are more complicated, and it's hard to discriminate the causalities between variables. Generally, sovereign default crisis are associated with lower GDP growth, low investment and inflation.

Sovereign default crisis eruption was rooted in the unhealthy financial system, and if the government influx of fiscal policy to stable local economy, however, it will threaten the fiscal position and results in sovereign default. To reduce the sovereign debt, the traditional methods 
are raising growth and government assets privatization. Or in untraditional way, they are debt restructuring, unanticipated inflation, and depressing financial repression (Reinhart, Reinhart and Rogoff, 2015).

In this paper, adopting Random Forest and Probit model, we want to compare the accuracy of default models and aim at concluding the main determinants for each default. In the past, Probit model was used to explore the impact of macroeconomic factors on financial crises. But the interdependence between variables weaken the influence on eruption of financial crises. Better than Probit model, Random Forest can detect variable interactions. And we aim at the importance of variables to find primary determinants of default. In addition, our sample encompass 66 countries, the period is 1970-2012, and we use yearly data. For the sample covers many countries, numerous explanatory variables and it's uncomplete dataset with much missing data. That's why we adopt the Random Forest ${ }^{1}$ to examine empirically.

In both two Probit model and Random Forest, the empirical results robustly point out the debtrelated variables dominants the external default. However, the macroeconomic-related variables dominants the domestic default. And, the burden of interest payments of external debt results in banking crisis.

The innovation and contribution of this paper are as follows. This paper strikes a more positive note than other recent papers on the usefulness of leading indicators in predicting default incidence. In spite of the differences in default characteristics across time and geography, the literature review identified a number of indicators that have proven consistently useful in explaining default incidence. These findings were confirmed by the empirical investigation.

\section{Literature Review}

\subsection{Stylized Facts}

During the period 1900-2008, global crises are banking crisis, currency crashes, sovereign default crisis, inflation crisis and depression in stock market. Reinhart and Trebesch (2016) focus on three periods, including (1) in the 1930s, banking crises occur after the economic mess of WWI. (2) in 1980-1990, the lost 10 years in developing countries. (3) the U.S. subprime mortgage crisis in 2007, and the derivative effects on the European sovereign debt crises. Banking crises and lost 10 years occurred in both developed and developing countries, and the

\footnotetext{
1 The advantages of Random Forest model are as follows: (1) It is one of the most accurate learning algorithms available. For many data sets, it produces a highly accurate classifier. (2) It runs efficiently on large databases, and it gives estimates of what variables are important in the classification. (3) It generates an internal unbiased estimate of the generalization error as the forest building progresses. (4) It has an effective method for estimating missing data and maintains accuracy when a large proportion of the data are missing. (5) It offers an experimental method for detecting variable interactions.
} 
subprime mortgage crisis took place in only developed countries.

What's the impact of sovereign default crisis on economic of a country? We first look at the influence of sovereign default on GDP. From Figure 1-3, it describes the changes of government debt. Our sample covers 66 countries, including 22 developed countries and 48 developing countries. After 2000, the external debt of developed countries arising. During the debt crises period, private sector external debt is usually absorbed by public sector external debt (Reinhart and Rogoff, 2009, 2011). Figure 1 describes the huge government debt of many countries, in the end of 1980s and early 1990s, the government debt to GDP amount to $100 \%$ in developing countries. In the aftermath of WW2 and 2010, the government debt to GDP amount to $90 \%$ in developed countries. Figure 2 shows the external debt erupted in the early 2000s in developed countries. For all Europe, external debt to GDP is more than twice threshold value (the threshold value is $90 \%$ ). Figure 3 describes the banking loan to GDP.

Based on the background, we find that the external debt increasing yearly, and it inspires us to discuss the overall main determinants.

\subsection{The determinants of sovereign default crisis}

The existing literature provide two categories of determinants in external default, and they are "Macroeconomic-related variables" and "Debt-related variables" separately (Das, Papaioannou and Trebesch, 2012). In this paper, the key variables in the literature are adopted. The classifications of several important factors are described as follows.

\subsubsection{Macroeconomic-related variables}

\subsubsection{Real GDP growth}

Reinhart, Reinhart and Rogoff (2012) argued that the relationship between debt and economic growth are dominated by business cycle or not? For the relationship is not significant in countries with lower debt to GDP. Reinhart and Rogoff (2009) referred domestic default always happened in local recession period. When external default erupted with domestic hyperinflation, it is always coincident with domestic default. We can see the relationship between external default and hyperinflation in many countries via domestic default.

\subsubsection{Inflation}

Cruces and Trebusch (2013) referred that in the aftermath of external default, the higher lending cost came from inflation. 


\subsubsection{Export, Current Account}

The ability of solving external debt can be accessed via export, and its importance is the same with GDP (Reinhart and Rogoff, 2009). It had been discussed that which factors have influence on international capital inflow to emerging countries (Cruces and Trebesch, 2013; Gelos, Sahay, and Sandleris, 2011). Especially, before the U.S. subprime mortgage crisis in 2008, the global imbalance may be important factors of sovereign debt crisis.

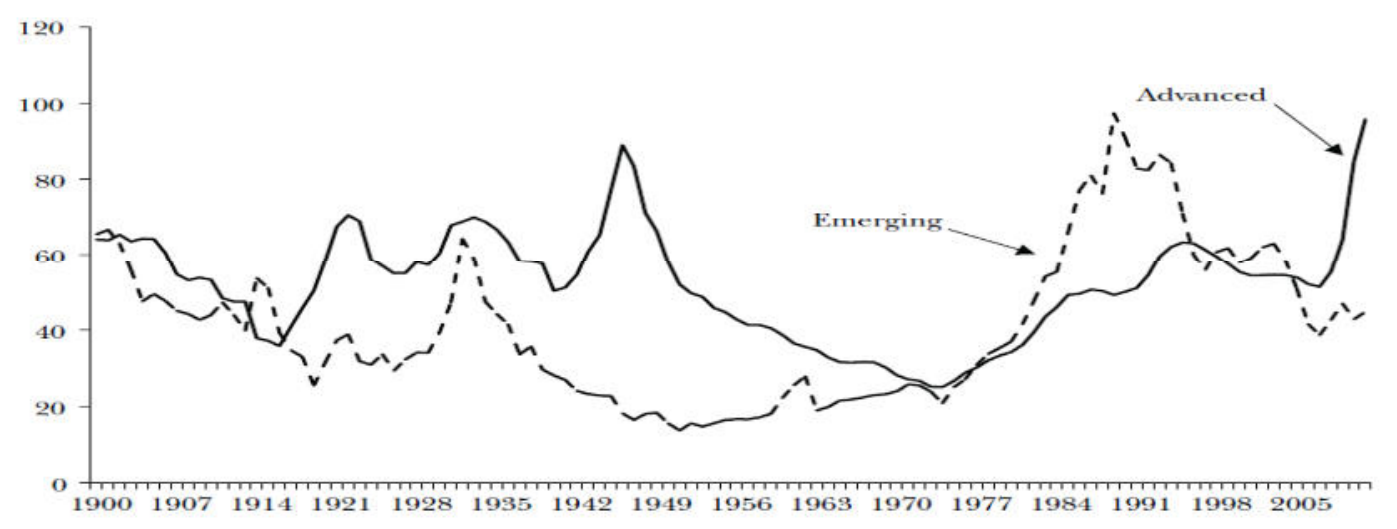

Figure 1 Government debt relative to GDP(1860-2011)

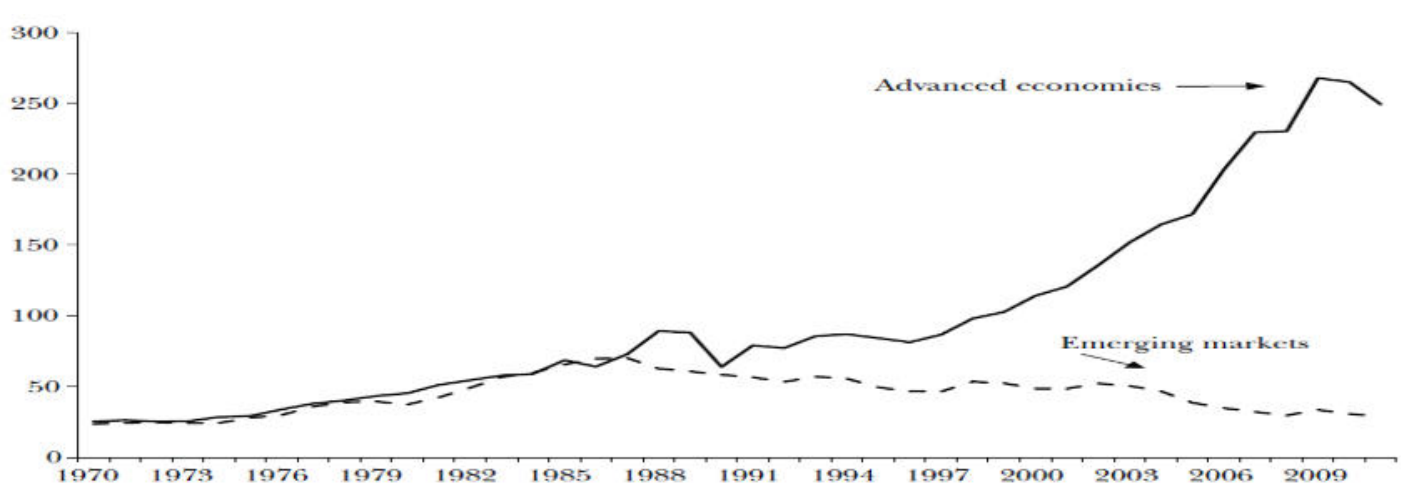

Figure 2 External debt relative to GDP(1970-2011)

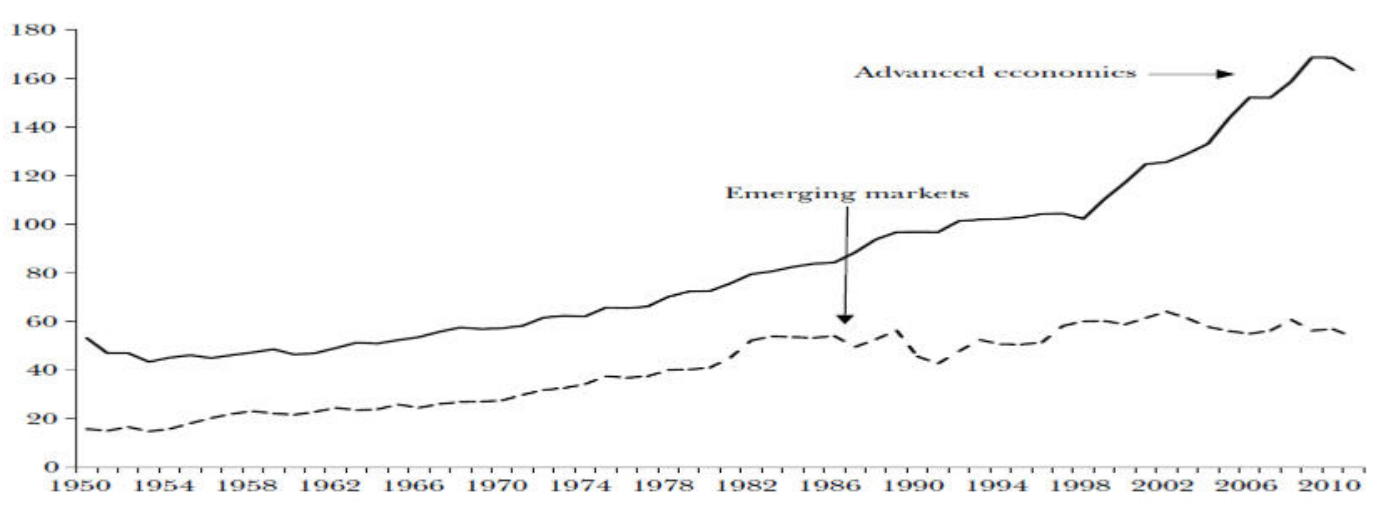

Figure 3 Private local debt relative to GDP(1950-2011)

Source : Reinhart, Reinhart and Rogoff(2012) 


\subsubsection{Monetary Policy}

Before and after debt crisis, the influence of monetary policy on debt crisis may be differ. Since the U.S. subprime mortgage crisis in 2008, it was proved that monetary policies can't prevent financial crisis spread (Reinhart and Rogoff, 2009). Reinhart and Trebesch (2016) conclude that after countries escape from sovereign default, even without haircut, monetary policy with dropping interest rate adopted by U.S. will reduce principal and interest payments and benefit debtor countries.

\subsubsection{Debt-related variables}

Indicators include debt burden, government debt, private debt and external debt. Debt relative to GDP is the most popular predicting indicator for external default, describing the past records of external default and inflation. Through this indicator, we figure out the huge government debt tolerance for a country (Reinhart, Rogoff and Savastano, 2003). Finger and Mecagni (2007) found most debt crises erupted at debt to GDP ratio arising more than 39\%. And, focus on developing countries, Manasse and Roubini (2009) analyzed the thresholds of "Debt relative to GDP", "Short-term debt relative to reserve" and "government debt relative to income".

\section{Empirical strategy and data}

\subsection{Data}

In this paper, we adopt the long-dated cross-country data on public debt developed by Reinhart and Rogoff (2009). This is the first complete dataset of domestic default and debt restructuring, covering 1800-2012. It includes 70 examples of legal domestic default, expressing principal payments suspension, principal and interest payment reduction unilaterally.

After 1980s, the legal examples of domestic default and debt reconstructing occur, and they occur at the same time. Reinhart and Rogoff (2009) define debt crisis including external default and domestic default, a sovereign default is defined as the failure of a government to meet a principal or interest payment on the due date. Definition of domestic default is the same as before, and it requires the banking deposits to be frozen, or convert the deposit from U.S. dollar to local currency.

We choose variables based on literatures, and Table 2 listed data sources. Using the debt crises dataset of Reinhart and Rogoff (2009), covering 66 countries in period 1970-2012 with yearly data, described in Table 1. For robust check, we use three models, including external default model (model 1), domestic default model (model 2) and banking crisis model (model 3). We 
aim at finding out the prominent factors of them. Examine with three different dependent variables, separately external default in model 1 , domestic default in model 2 , and banking crisis in model 3, and they are dummy variables. When default or crisis erupted in this year, it is 1 , otherwise 0 . For comparative, we further separate the sample as three periods, and they are 1970 to 2012,1980 to 2012 and 1990 to $2012 .^{2}$

\subsection{Empirical methods}

As for model specification, different approaches have been explored about the nature of sovereign default. They are separately approaches, based on reduced-form models (Duffie et al., 2003), based on structural models (Gapen et al., 2005), and pure statistical approaches whose objective is mainly to predict defaults in a way that is only loosely connected to the theory.About the third approach, it is said that the different modeling approaches employed in the leading indicators literature can be broadly grouped into four categories. (Abiad, 2002)

(1) The first category uses logit/ probit models.

(2) The second category, known as the non-parametric, indicators, or signals approach.

(3) The third category employs a qualitative and quantitative analysis of the behavior of various variables around crisis occurrence by splitting countries into a crisis and non-crisis control group.

(4) The fourth category uses more innovative techniques to identify and explain crisis incidence, including the use of binary recursive trees, artificial neural networks, and Markov switching models.

In this paper, we belong to the third approach. And we adopt the fourth innovative method, that's Random Forest model.

Probit model was generally used to explore financial crises, based on the probabilities of conditional predictions in several explanatory variables. The advantages of Probit model originating from its ability of separating the marginal effects in each explanatory variable, and assuming others are fixed at average value. But the performance of out of sample prediction is always not good, it may comes from the reasons and influence on crises varying from time period and countries and the missing political factors or others. In Probit model, it could describe the interdependence with much more dummy variables interaction terms. However, this way can't work. The causality of sovereign default determinants is hard to discriminate, and the channels of dealing with sovereign default by government are not independent, several channels combined in operation.

Why we adopt Random Forest model to examine empirically? For the characteristics of

\footnotetext{
${ }^{2}$ For the data limitation, external default covers from 1970-2008, domestic default covers from 19702012, and banking crises cover 1970-2008.
} 
measuring importance of variables, and it detects variable interactions resulting in sovereign default. In this paper, we estimate with Probit model, then Random Forest model.

\subsubsection{STEP1: traditional Probit model}

In the binary response model, the principle concern is with the response probability,

$$
\operatorname{Pr}(\mathrm{y}=1 \mid \mathrm{x})=\operatorname{Pr}\left(\mathrm{y}=1 \mid x_{1}, x_{2}, \ldots ., x_{k}\right)
$$

Suppose what we are examining is the probability of sovereign default, then y could be 1 if sovereign default happens, and 0 otherwise. While $\mathrm{x}$ would include a set of characteristics. The Probit model can be derived from a latent variable model. Let $y^{*}$ be an unobserved or latent variable determined by,

$$
y^{*}=\beta_{0}+\beta_{1} x_{1}+\beta_{2} x_{2}+\cdots+\beta_{k} x_{k}+\varepsilon
$$

The idea here is that the observed variable, $y$, will take on a value of 1 if $y^{*}$ is greater than 0 $\mathbb{I}\left(y^{*}>0\right)$, and 0 otherwise, where $\mathbb{I}($.$) is an indicator function, and takes on the value 1$ if the term in brackets is true. In order to estimate this function, we will still assume that the expected value of the error terms given the independent variables is 0 , i.e. that there are uncorrelated. The distribution of the error term is dependent on the underlying assumption made about $\mathrm{F}$ (.) of course (note that both Logistic and Normal distribution functions are symmetric about 0 ). Given the assumptions on the distribution functions, and the specification for the latent variables, we can derive the response probabilities then,

$$
\begin{gathered}
\operatorname{Pr}(\mathrm{y}=1 \mid \mathrm{x})=\operatorname{Pr}\left(y^{*}>0 \mid x\right)=\operatorname{Pr}\left(\epsilon>-\beta_{0}-\beta_{1} x_{1}-\beta_{2} x_{2}-\cdots-\beta_{k} x_{k} \mid x\right) \\
=1-F\left(-\beta_{0}-\beta_{1} x_{1}-\beta_{2} x_{2}-\cdots-\beta_{k} x_{k} \mid x\right)=F\left(\beta_{0}+\beta_{1} x_{1}+\beta_{2} x_{2}+\cdots+\beta_{k} x_{k}\right)
\end{gathered}
$$

Table 1

\begin{tabular}{|l|l|}
\hline Region & Country \\
\hline Africa & $\begin{array}{l}\text { Algeria, Angola, Central African Republic, Cote D'Ivoire, Egypt, Kenya, Mauritius, Morocco, Nigeria, South } \\
\text { Africa, Tunisia, Zambia, Zimbabwe }\end{array}$ \\
\hline Asia & $\begin{array}{l}\text { China, India, Indonesia, Japan, Korea, Malaysia, Myanmar (Burma), Philippines, Singapore, Sri Lanka, } \\
\text { Taiwan, Thailand }\end{array}$ \\
\hline Europe & $\begin{array}{l}\text { Austria, Belgium, Denmark, Finland, France, Germany, Greece, Italy, Netherlands, Norway, Portugal, Spain, } \\
\text { Sweden, United Kingdom, Hungary, Poland, Romania, Russia, Turkey }\end{array}$ \\
\hline Latin America & $\begin{array}{l}\text { Argentina, Bolivia, Brazil, Chile, Colombia, Costa Rica, Dominican Republic, Ecuador, El Salvador, } \\
\text { Guatemala, Honduras, Mexico, Nicaragua, Panama, Paraguay, Peru, Uruguay, Venezuela }\end{array}$ \\
\hline North America & Canada, United States \\
\hline Oceania & Australia, New Zealand \\
\hline
\end{tabular}


Table 2

\begin{tabular}{|c|c|c|c|}
\hline Variable & Definition & Source & Category \\
\hline Y & $\begin{array}{l}\text { External debt default(Model 1) } \\
\text { Domestic debt default(Model 2) } \\
\text { Banking crises (Model 3) }\end{array}$ & Reinhart and Rogoff(2009) & Dummy \\
\hline $\mathrm{X} 1$ & Composite inflation series & World Development Indicators & Macroeconomic-related \\
\hline $\mathrm{X} 2$ & External balance on goods and services/ GDP & World Development Indicators & Macroeconomic-related \\
\hline $\mathrm{X} 3$ & GDP growth & World Development Indicators & Macroeconomic-related \\
\hline $\mathrm{X} 4$ & Inflation & World Development Indicators & Macroeconomic-related \\
\hline $\mathrm{X} 5$ & Broad money/GDP & World Development Indicators & Macroeconomic-related \\
\hline X6 & Total reserves / Imports & World Development Indicators & Macroeconomic-related \\
\hline $\mathrm{X} 7$ & Public debt/GDP & Reinhart and Rogoff(2009) & Debt-related \\
\hline $\mathrm{X} 8$ & Domestic debt/Total public debt & Reinhart and Rogoff(2009) & Debt-related \\
\hline X9 & External debt stocks/GNI & World Development Indicators & Debt-related \\
\hline $\mathrm{X} 10$ & Domestic credit to private sector/GDP & World Development Indicators & Debt-related \\
\hline $\mathrm{X} 11$ & Interest payments on external debt/GNI & World Development Indicators & Debt-related \\
\hline $\mathrm{X} 12$ & Debt service & World Development Indicators & Debt-related \\
\hline $\mathrm{X} 13$ & Short term debt/Total external debt & World Development Indicators & Debt-related \\
\hline
\end{tabular}

1.The empirical model is equation (8): $Y_{i, t}^{*}=\alpha+\gamma^{\prime} Z_{i, t-1}+\theta^{\prime} D_{i, t-1}+\varepsilon_{i, t} . Y_{i, t}^{*}=1$, if external debt default (or domestic debt default, or banking crisis) erupts; and $Y_{i, t}^{*}=0$, if there's no external debt default (or domestic debt default, or banking crisis). $Z_{i, t-1}$ is a set of macroeconomic variables in i country, at t-1 period. And $D_{i, t-1}$ is a set of debt-related variables in i country, at t-1 period. $\gamma \cdot \theta$ should be estimated.

Because $y^{*}$ typically does not have a measure that is easily interpretable, when examining the effect of the independent variable, we examine it in relation to the effect it has on $\operatorname{Pr}(y=1 \mid x)$. Suppose we have on hand $\mathrm{n}$ observations for all the variables. Then the probability of observing any outcome is just,

$$
L_{i}\left(y_{i} \mid x_{i} ; \beta\right)=\left(F\left(x_{i} \beta\right)_{i}^{y}\left(1-F\left(x_{i} \beta\right)\right)^{1-y_{i}}\right)
$$

The log Likelihood function for the entire sample is just

$$
l_{i}(\beta)=\sum_{i=1}^{n} y_{i} \log \left(F\left(x_{i} \beta\right)\right)+\sum_{i=1}^{n}\left(1-y_{i}\right) \log \left(1-F\left(x_{i} \beta\right)\right)=\sum_{i=1}^{n} l_{i}(\beta)
$$

Under general assumptions, the estimates of the coefficients using MLE are consistent, asymptotically normal and coefficients.

We choose two categories of explanatory variables: (1) Macroeconomic-related variables $\left(Z_{i, t-1}\right)$ : Composite Inflation Series $、$ External Balance on Goods and Services relative to GDP 、 GDP Growth 、Inflation 、 Broad Money relative to GDP 、 Total Reserves in Months of Imports. (2) Debt-related variables $\left(D_{i, t-1}\right)$ : Public Debt relative to GDP 、 Domestic debt relative to Total 
Public Deb 、 External Debt Stocks relative to GNI 、 Domestic Credit to Private Sector relative to GDP 、 Interest Payments on External Debt relative to GNI 、 Debt Service 、 Short-term Debt relative to Total External Debt.

The empirical model is $Y_{i, t}^{*}=\alpha+\gamma^{\prime} Z_{i, t-1}+\theta^{\prime} D_{i, t-1}+\varepsilon_{i, t}$

While estimating by probit model, we choose three categories variables. Their definitions are as follows.(1) $Y_{i, t}^{*}=1$, if external default(or domestic default, or banking crisis) erupts. $Y_{i, t}^{*}=$ 0 , if there's no external default(or domestic default, or banking crisis). (2) $Z_{i, t-1}$, a set of macroeconomic-related variables in i country, at t-1 period. (3) $D_{i, t-1}$, a set of debt-related variables in i country, at $\mathrm{t}-1$ period. And $\gamma \cdot \theta$ should be estimated.

However, the Probit model can't correctly capture the interdependence of explanatory variables, inducing the eruption of external debt. Then, we use random forest model to do robust check.

\subsubsection{STEP2 : Random Forest model}

Random forests are a combination of tree predictors such that each tree depends on the values of a random vector sampled independently and with the same distribution for all trees in the forest.

The common element in all of these procedures is that for the kth tree, a random vector $\Theta_{k}$ is generated, independent of the past random vectors $\Theta_{1}, \ldots \ldots \Theta_{k-1}$ but with the same distribution; and a tree is grown using the training set and $\Theta_{k}$, resulting in a classifier $h\left(\mathbf{x}, \Theta_{k}\right)$ where $\mathbf{x}$ is an input vector. For instance, in bagging the random vector $\Theta$ is generated as the counts in $\mathrm{N}$ boxes resulting from $\mathrm{N}$ darts thrown at random at the boxes, where $\mathrm{N}$ is number of examples in the training set. In random split selection $\Theta$ consists of a number of independent random integers between 1 and $\mathrm{K}$. The nature and dimensionality of $\Theta$ depends on its use in tree construction.

After a large number of trees is generated, they vote for the most popular class. We call these procedures random forests. A random forest is a classifier consisting of a collection of tree structured classifiers $\left\{h\left(\mathbf{x}, \Theta_{k}\right), k=1, \ldots ..\right\}$ where the $\left\{\Theta_{k}\right\}$ are independent identically distributed random vectors and each tree casts a unit vote for the most popular class at input $\mathrm{x}$.

\subsubsection{Random Forests for Regression}

Random forests for regression are formed by growing trees depending on a random vector $\Theta$ such that the tree predictor $h(\mathbf{x}, \Theta)$ takes on numerical values as opposed to class labels. The output values are numerical and we assume that the training set is independently drawn from the distribution of the random vector $\mathrm{Y}, \mathrm{X}$. The mean-squared generalization error for any 
numerical predictor $\mathrm{h}(\mathbf{x})$ is $E_{X, Y}(Y-h(\mathbf{x}))^{2}$.

The random forest predictor is formed by taking the average over k of the trees $h\left(\mathbf{x}, \Theta_{k}\right)$. Define the average generalization error of a tree as: $P E^{*}($ tree $)=E_{\Theta} E_{X, Y}(Y-h(\mathbf{x}, \Theta))^{2}$.

Assume that for all $\Theta, E Y=E_{X} \mathrm{~h}(\mathbf{x}, \Theta)$. Then

$$
P E^{*}(\text { forest }) \leq \bar{\rho} P E^{*}(\text { tree })
$$

PE*(forest) is the generalization error of the forest. Where $\bar{\rho}$ is the weighted correlation between the residuals $\mathrm{Y}-\mathrm{h}(\mathbf{x}, \Theta)$ and $\mathrm{Y}-\mathrm{h}\left(\mathbf{x}, \Theta^{\prime}\right)$ Where $\Theta, \Theta^{\prime}$ are independent.

$\mathrm{P} E^{*}($ forest $)=E_{\boldsymbol{X}, Y}\left[\mathrm{E}_{\Theta}(\mathrm{Y}-\mathrm{h}(\mathbf{x}, \Theta))\right]^{2}=E_{\Theta} E_{\Theta^{\prime}} E_{\boldsymbol{X}, Y}(Y-h(\mathbf{x}, \Theta))\left(Y-h\left(\mathbf{x}, \Theta^{\prime}\right)\right)$

The term on the right in (7) is a covariance and can be written as: $E_{\Theta} E_{\Theta^{\prime}}\left(\rho\left(\Theta, \Theta^{\prime}\right) s d(\Theta) s d\left(\Theta^{\prime}\right)\right)$

Where $\operatorname{sd}(\Theta)=\sqrt{E_{X, Y}(Y-h(\mathbf{x}, \Theta))^{2}}$ Define the weighted correlation as:

$\bar{\rho}=E_{\Theta} E_{\Theta^{\prime}}\left(\rho\left(\Theta, \Theta^{\prime}\right)\right) s d(\Theta) s d\left(\Theta^{\prime}\right) /\left(E_{\Theta} s d(\Theta)\right)^{2}$

Then $P E^{*}($ forest $)=\bar{\rho}\left(E_{\Theta} s d(\Theta)\right)^{2} \leq \bar{\rho} P E^{*}($ tree $)$

Equation (6) pinpoints the requirements for accurate regression forests-low correlation between residuals and low error trees. The random forest decreases the average error of the trees employed by the factor $\bar{\rho}$. The randomization employed needs to aim at low correlation.

\subsubsection{Estimating the importance of each predictor}

Denote by $\hat{e}$ the OOB(out-of-bag) error rate estimate of the loss when using original training set, D. For each predictor $x_{p}$, where $\mathrm{p} \in\{1,2, \ldots, k\}$.Randomly permute $\mathrm{p}_{t h}$ predictor to generate a new set of samples $D^{\prime}=\left\{\left(y_{1}, x_{1}^{\prime}\right), \ldots .\left(y_{N}, x^{\prime}{ }_{N}\right)\right\}$. Compute OOB estimate $\hat{e}_{k}$ of prediction error with the new samples. A measure of importance of predictor $x_{p}$ is $\hat{e}_{k}-\hat{e}$, the increase in error due to random perturbation of $\mathrm{p}_{t h}$ predictor. The equation of OOB error (out of bagging error) is as follows. $\mathrm{P}$ is the average correlation of trees, $\mathrm{S}$ is the strength of trees.

OOB error $\leq \frac{P\left(1-S^{2}\right)}{S^{2}}$ 


\section{Empirical results}

Tables 3 lists the Random Forest results of three models, separately external default model, domestic default model and banking crisis model, and in three time periods. Compare with models through 4 indicators, OOB estimate of error rate, Accuracy rate, Sensitivity, and Specificity $^{3}$. Obviously, the domestic default model has better performance, then external default model and banking crisis model. It shows the two categories of variables can explain domestic default well.

Table 4 shows the variable importance of external default. Through 2 indicators, separately" Mean Decrease Accuracy" and "Mean Decrease Gini", we find "External Debt Stocks relative to GNI","Public Debt relative to GDP", "Domestic Debt relative to Total Public Debt" and "Inflation" have higher importance in external default. Those debt-related variables are primary reasons for external default eruption.

Table 5 shows the variable importance of domestic default. We find "External balance on goods and services relative to GDP", "GDP growth", "Short Term Debt relative to Total External Debt", "Inflation" have higher importance. Those macroeconomic-related variables reflect the economic background of countries. It tells us that the primary determinants of domestic default originating from the consolidating level of economic structure.

Table 6 shows the variable importance of banking crisis. We find "External Debt Stocks relative to GNI", "Interest Payments On External Debt relative to GNI", "Debt service", "External balance on goods and services relative to GDP" have higher importance on eruption of banking crisis.

For robust check, Table 7, Table 8 and Table 9 show the results of Probit models. And findings of both probit model and random forest model are almost the same. Showing our findings are

3 Those indicators are based on the accuracy in classification. According to "Confusion matrix" as follows:

\begin{tabular}{|c|c|c|c|}
\hline \multirow[b]{3}{*}{ Actual Class } & & \multicolumn{2}{|c|}{ Predicted Class } \\
\hline & & 0 & 1 \\
\hline & 0 & $\mathrm{a}$ & $\mathrm{b}$ \\
\hline & 1 & $\mathrm{c}$ & d \\
\hline
\end{tabular}

Hence, those indicators are concluded. (1). "OOB estimate of error rate": OOB error $\leq \frac{\mathrm{P}\left(1-\mathrm{S}^{2}\right)}{\mathrm{S}^{2}}, \mathrm{P}$ is the average correlation of trees, $\mathrm{S}$ is the strength of trees. (2). Accuracy rate $=1$ - OOB estimate. (3).Sensitivity $=$ $\left(\frac{a}{a+b}\right) \times 100 \%$. (4).Specificity $=\left(\frac{d}{c+d}\right) \times 100 \%$. 
robust. In Table 7," Public Debt relative to GDP", "External debt stocks relative to GNI" have higher importance on eruption of external default. Results in Table 7 is correspond to those in Table 4, the primary determinants of external default are debt-related variables. In Table 8, "External balance on goods and services relative to GDP", "GDP growth", "Inflation" have higher importance on eruption of domestic default. Results in Table 8 is correspond to those in Table 5, the primary determinants of domestic default are macroeconomic-related variables. In Table 9, "Public Debt relative to GDP", "Interest payments on external deb" have higher importance on eruption of banking crisis. Results in Table 9 is correspond to those in Table 6, the primary determinants of banking crisis are debt-related variables.

\section{Conclusion}

Through both Probit model and Random Forest model, we got robust empirical results. That's debt-related variables have higher importance on eruption of external default. And, macroeconomic-related variables reflecting the economic background of a country have higher importance on eruption of domestic default. In addition, "the interest payments from debt" have higher importance on eruption of banking crisis. Especially, the determinants of external default are corresponding with those of banking crisis. It describes the historical experience, before the eruption of external default in many countries, there always occur banking crisis. In the past, literature points out the relationship between macroeconomic variables and debt default is not robust, and the empirical results are hard to conclude. However, in this paper, we got robust results in both Probit model and Random Forest model. Reflecting that "macroeconomicrelated variables", "debt-related variables" are indeed important determinants of external default, domestic default and banking crisis. The key policy implications can be derived from this analysis. "External debt stock" stands out as a key leading indicator of external default as

Table 3 Random Forest Model Results

\begin{tabular}{|c|c|c|c|c|c|}
\hline Model & Time Period & $\begin{array}{c}\text { OOB estimate } \\
\text { of error rate(\%) }\end{array}$ & Accuracy rate(\%) & Sensitivity(\%) & Specificity(\%) \\
\hline \multirow{3}{*}{ External default (Model 1) } & $1970-2010$ & $7.6 \%$ & $92.4 \%$ & $98.1 \%$ & $65.3 \%$ \\
& $1980-2010$ & $7.1 \%$ & $92.9 \%$ & $97.8 \%$ & $71.3 \%$ \\
& $1990-2010$ & $8.1 \%$ & $91.9 \%$ & $98.1 \%$ & $56.4 \%$ \\
\hline \multirow{3}{*}{ Domestic default (Model 2) } & $1970-2010$ & $3.6 \%$ & $96.4 \%$ & $100.0 \%$ & $8.7 \%$ \\
& $1980-2010$ & $3.8 \%$ & $96.2 \%$ & $100.0 \%$ & $13.0 \%$ \\
\hline \multirow{3}{*}{ Banking crisis (Model 3) } & $1990-2010$ & $2.6 \%$ & $97.4 \%$ & $100.0 \%$ & $9.1 \%$ \\
& $1970-2010$ & $14.7 \%$ & $85.3 \%$ & $98.9 \%$ & $24.3 \%$ \\
& $1980-2011$ & $16.3 \%$ & $83.7 \%$ & $98.3 \%$ & $25.5 \%$ \\
\hline
\end{tabular}


Table4 Variable importance in External default Model (Model 1)

\begin{tabular}{|c|c|c|c|c|c|}
\hline \multicolumn{6}{|c|}{ Random Forest / Variable Importance Ranking } \\
\hline Time Period & Importance Ranking & variable & Mean Decrease Accuracy & variable & Mean Decrease Gini \\
\hline \multirow{4}{*}{ 1970-2008 } & 1 & External Debt Stocks/GNI & 32.06 & External Debt Stocks/GNI & 31.04 \\
\hline & 2 & Public Debt/GDP & 26.65 & Public Debt/GDP & 19.01 \\
\hline & 3 & Domestic Debt/Total Public Debt & 20.75 & Inflation & 16.63 \\
\hline & 4 & Inflation & 20.48 & Composite inflation series & 14.33 \\
\hline \multirow{4}{*}{$1980-2008$} & 1 & Public Debt/GDP & 30.23 & External Debt Stocks/GNI & 28.63 \\
\hline & 2 & External Debt Stocks/GNI & 30.22 & Public Debt/GDP & 20.86 \\
\hline & 3 & Inflation & 20.82 & Inflation & 13.76 \\
\hline & 4 & Interest Payments On External Debt/GNI & 20.58 & Composite inflation series & 12.87 \\
\hline \multirow{4}{*}{$1990-2008$} & 1 & External Debt Stocks/GNI & 25.04 & External Debt Stocks/GNI & 16.48 \\
\hline & 2 & Domestic Debt/Total Public Debt & 20.86 & Domestic Debt/Total Public Debt & 10.65 \\
\hline & 3 & Public Debt/GDP & 20.59 & Public Debt/GDP & 9.65 \\
\hline & 4 & Inflation & 17.16 & Inflation & 7.71 \\
\hline
\end{tabular}

1.The Variable Importance Ranking comes from the results of Random Forest model. According to "Mean Decrease Accuracy indicator" and "Mean Decrease Gini indicator", we rank the importance of variables. 2. "Mean Decrease Accuracy" shows the accuracy will be decreased without this variable. Hence, the larger the indicator the mor e importance this variable has. 3. "Mean Decrease Gini" is a measure of variable importance based on the Gini impurity index used for the calculation of splits during training. Hence, the larger the indicator the more importan ce this variable has. Here is the explanation from the randomForest package written by Breiman and Cutler:

---Gini importance: Every time a split of a node is made on variable $m$ the gini impurity criterion for the two descendent nodes is less than the par ent node. Adding up the gini decreases for each individual variable over all trees gives a fast variable importance that is often very consistent with the permutation importance measure. ---

The Gini impurity index is defined as $\sum_{i=1}^{n_{c}} p_{i}\left(1-p_{i}\right)$, where $\mathrm{n}_{c}$ is the number of classes in the target variable and $p_{i}$ is the ratio of this class. The importance is then calculated as, $\mathrm{I}=G_{p a r e n t}-$ $G_{\text {split } 1}-G_{\text {split } 2}$, averaged over all splits in the forest involving the predictor in question. As this is an average it could easily be extend ed to be averaged over all splits on variables contained in a group. 
Table 5 Variable importance in Domestic default Model (Model 2)

\begin{tabular}{|c|c|c|c|c|c|}
\hline \multicolumn{6}{|c|}{ Random Forest / Variable Importance Ranking } \\
\hline Time Period & Importance Ranking & variable & Mean Decrease Accuracy & variable & Mean Decrease Gini \\
\hline \multirow{4}{*}{$1970-2012$} & 1 & External balance on goods and services/ GDP & 17.30 & External balance on goods and services/GDP & 6.16 \\
\hline & 2 & Short Term Debt/Total External Debt & 12.00 & GDP growth annual & 4.36 \\
\hline & 3 & Inflation & 11.47 & Short Term Debt/Total External Debt & 4.20 \\
\hline & 4 & Domestic Debt/Total Public Debt & 9.50 & Inflation & 4.03 \\
\hline \multirow{4}{*}{$1980-2012$} & 1 & External balance on goods and services/ GDP & 21.68 & External balance on goods and services/ GDP & 6.88 \\
\hline & 2 & Short Term Debt/Total External Debt & 12.43 & Inflation & 4.11 \\
\hline & 3 & Inflation & 12.27 & Short Term Debt/Total External Debt & 4.01 \\
\hline & 4 & Debt service & 10.29 & GDP growth annual & 3.96 \\
\hline \multirow{4}{*}{$1990-2012$} & 1 & External balance on goods and services/ GDP & 18.74 & External balance on goods and services/ GDP & 4.12 \\
\hline & 2 & Short Term Debt/Total External Debt & 9.78 & Inflation & 2.11 \\
\hline & 3 & Inflation & 9.14 & Broad Money/GDP & 1.80 \\
\hline & 4 & Interest Payments On External Debt/GNI & 8.85 & Composite inflation series & 1.72 \\
\hline
\end{tabular}

1.The Variable Importance Ranking comes from the results of Random Forest model. According to "Mean Decrease Accuracy indicator" and "Mean Decrease Gini indicator", we rank the importance of variables. 2. "Mean Decrease Accuracy" shows the accuracy will be decreased without this variable. Hence, the larger the indicator the more importance this variable has. 3. "Mean Decrease Gini" is a measure of variable importance based on the Gini impurity index used for the calculation of splits during training. Hence, the larger the indicator the more importan ce this variable has. Here is the explanation from the randomForest package written by Breiman and Cutler:

---Gini importance: Every time a split of a node is made on variable $\mathrm{m}$ the gini impurity criterion for the two descendent nodes is less than the par ent node. Adding up the gini decreases for

each individual variable over all trees gives a fast variable importance that is often very consistent with the permutation importance measure. ---

The Gini impurity index is defined as $\sum_{i=1}^{n_{c}} p_{i}\left(1-p_{i}\right)$, where $\mathrm{n}_{c}$ is the number of classes in the target variable and $p_{i}$ is the ratio of this class. The importance is then calculated as, $\mathrm{I}=G_{p a r e n t}-$ $G_{\text {split } 1}-G_{\text {split } 2}$, averaged over all splits in the forest involving the predictor in question. As this is an average it could easily be extend ed to be averaged over all splits on variables contained in a group. 
Table 6 Variable importance in Banking crisis Model (Model 3)

\begin{tabular}{|c|c|c|c|c|c|}
\hline \multicolumn{6}{|c|}{ Random Forest / Variable Importance Ranking } \\
\hline Time Period & Importance Ranking & variable & Mean Decrease Accuracy & variable & Mean Decrease Gini \\
\hline \multirow{4}{*}{ 1970-2008 } & 1 & Interest Payments On External Debt/GNI & 23.80 & External Debt Stocks/GNI & 17.41 \\
\hline & 2 & External Debt Stocks/GNI & 22.37 & Interest Payments On External Debt/GNI & 16.97 \\
\hline & 3 & Domestic Debt/Total Public Debt & 19.73 & Debt service & 14.26 \\
\hline & 4 & Debt service & 19.55 & External balance on goods and services/ GDP & 14.01 \\
\hline \multirow{4}{*}{ 1980-2008 } & 1 & External Debt Stocks/GNI & 22.95 & External Debt Stocks/GNI & 15.67 \\
\hline & 2 & Interest Payments On External Debt/GNI & 20.14 & Interest Payments On External Debt/GNI & 15.61 \\
\hline & 3 & Debt service & 19.33 & External balance on goods and services/ GDP & 14.33 \\
\hline & 4 & Domestic Debt/Total Public Debt & 18.82 & Debt service & 13.27 \\
\hline \multirow{4}{*}{ 1990-2008 } & 1 & Interest Payments On External Debt/GNI & 23.80 & External Debt Stocks/GNI & 17.41 \\
\hline & 2 & External Debt Stocks/GNI & 22.37 & Interest Payments On External Debt/GNI & 16.97 \\
\hline & 3 & Domestic Debt/Total Public Debt & 19.73 & Debt service & 14.26 \\
\hline & 4 & Debt service & 19.55 & External balance on goods and services/ GDP & 14.01 \\
\hline
\end{tabular}

1.The Variable Importance Ranking comes from the results of Random Forest model. According to "Mean Decrease Accuracy indicator" and "Mean Decrease Gini indicator", we rank the importance of variables. 2. "Mean Decrease Accuracy" shows the accuracy will be decreased without this variable. Hence, the larger the indicator the mor e importance this variable has. 3. "Mean Decrease Gini" is a measure of variable importance based on the Gini impurity index used for the calculation of splits during training. Hence, the larger the indicator the more importance this variable has. Here is the explanation from the randomForest package written by Breiman and Cutler:

---Gini importance: Every time a split of a node is made on variable $m$ the gini impurity criterion for the two descendent nodes is less than the parent node. Adding up the gini decreases for each individual variable over all trees gives a fast variable importance that is often very consistent with the permutation importance measure. ---

The Gini impurity index is defined as $\sum_{i=1}^{n_{c}} p_{i}\left(1-p_{i}\right)$, where $\mathrm{n}_{c}$ is the number of classes in the target variable and $p_{i}$ is the ratio of this class. The importance is then calculated as, $\mathrm{I}=G_{\text {parent }}-$ $G_{\text {split } 1}-G_{\text {split } 2}$, averaged over all splits in the forest involving the predictor in question. As this is an average it could easily be extend ed to be averaged over all splits on variables contained in a group. 
Table 7 Probit Model (External default Model, Model 1)

\begin{tabular}{|c|c|c|c|c|c|c|c|c|c|c|c|c|}
\hline \multirow{2}{*}{$\frac{\text { Time Period }}{\text { Variables }}$} & \multicolumn{4}{|c|}{$1990-2008$} & \multicolumn{4}{|c|}{$1980-2008$} & \multicolumn{4}{|c|}{$1970-2008$} \\
\hline & Estimate & Std. Error & $\mathrm{z}$ v value & $\operatorname{Pr}(>|z|)$ & Estimate & Std. Errc & $\mathrm{z}$ z value & $\operatorname{Pr}(>|z|)$ & Estimate & Std. Error & $z$ value & $\operatorname{Pr}(>|z|)$ \\
\hline Intercept & -1.537 & 0.767 & -2.003 & $0.045 *$ & -2.273 & 0.632 & -3.596 & $0.0003 * * *$ & -2.359 & 0.573 & -4.116 & $0.00004 * * *$ \\
\hline Public Debt/GDP & 0.025 & 0.007 & 3.524 & $0.0004 * * *$ & 0.032 & 0.006 & 5.020 & $0.000001 * * *$ & 0.032 & 0.006 & 5.573 & $0.00000003 * * *$ \\
\hline Domestic Debt/Total Public Debt & -2.646 & 1.083 & -2.444 & $0.015 *$ & -1.238 & 0.665 & -1.863 & 0.062 . & -0.243 & 0.571 & -0.426 & 0.670 \\
\hline Composite inflation series & 0.059 & 0.036 & 1.648 & 0.099 & -0.008 & 0.021 & -0.390 & 0.697 & -0.003 & 0.018 & -0.155 & 0.877 \\
\hline External balance on goods and services/GDP & -0.043 & 0.021 & -2.066 & $0.039 *$ & -0.026 & 0.018 & -1.418 & 0.156 & -0.016 & 0.017 & -0.944 & 0.345 \\
\hline GDP growth & -0.014 & 0.037 & -0.386 & 0.700 & -0.026 & 0.027 & -0.973 & 0.331 & -0.032 & 0.025 & -1.295 & 0.195 \\
\hline Inflation & -0.054 & 0.037 & -1.447 & 0.148 & 0.020 & 0.022 & 0.912 & 0.362 & 0.012 & 0.018 & 0.655 & 0.512 \\
\hline Broad money/GDP & 0.010 & 0.017 & 0.584 & 0.559 & -0.018 & 0.011 & -1.587 & 0.113 & -0.028 & 0.010 & -2.843 & $0.004 * *$ \\
\hline Total reserves in months of imports & -0.050 & 0.065 & -0.778 & 0.437 & -0.025 & 0.054 & -0.458 & 0.647 & 0.006 & 0.048 & 0.121 & 0.904 \\
\hline External debt stocks/ GNI & 0.026 & 0.008 & 3.150 & $0.002 * *$ & 0.019 & 0.006 & 2.972 & $0.003 * *$ & 0.019 & 0.006 & 3.165 & $0.002 * *$ \\
\hline Domestic credit to private sector/GDP & -0.043 & 0.016 & -2.691 & $0.007 * *$ & -0.020 & 0.010 & -2.012 & $0.044 *$ & -0.013 & 0.009 & -1.449 & 0.147 \\
\hline Interest payments on external debt/GNI & -0.353 & 0.135 & -2.612 & $0.009 * *$ & -0.067 & 0.085 & -0.790 & 0.429 & -0.103 & 0.081 & -1.265 & 0.206 \\
\hline Debt service & 0.023 & 0.021 & 1.081 & 0.280 & 0.010 & 0.014 & 0.734 & 0.463 & 0.011 & 0.012 & 0.892 & 0.372 \\
\hline Short Term Debt/Total External Debt & 0.001 & 0.015 & 0.059 & 0.953 & 0.012 & 0.012 & 0.968 & 0.333 & 0.013 & 0.011 & 1.162 & 0.245 \\
\hline Log likelihood & -73.47627 & & & & -109.004 & & & & -126.3597 & & & \\
\hline LR statistic & 164.1123 & & & & 269.4207 & & & & 268.5686 & & & \\
\hline Prob. (LR statistic) & 0.000000 & & & & 0.000000 & & & & 0.000000 & & & \\
\hline McFadden R-squared & 0.527582 & & & & 0.552738 & & & & 0.515202 & & & \\
\hline Sum squared residual & 22.45801 & & & & 32.66127 & & & & 36.83000 & & & \\
\hline
\end{tabular}

1.The empirical model is equation (8): $Y_{i, t}^{*}=\alpha+\gamma^{\prime} Z_{i, t-1}+\theta^{\prime} D_{i, t-1}+\varepsilon_{i, t} . Y_{i, t}^{*}=1$, if external debt default (or domestic debt default, or banking crisis) erupts; and $Y_{i, t}^{*}=0$, if there's no external debt default (or domestic debt default, or banking crisis). $Z_{i, t-1}$ is a set of macroeconomic variables in i country, at t-1 period. And $D_{i, t-1}$ is a set of debt-related variables in i country, at t-1 period. $\gamma \cdot \theta$ should be estimated. $2 . * * * * * *$ Significant at the $0.10,0.05$ and 0.01 , levels, respectively. 
Table 8 Probit Model (Domestic default Model, Model 2)

\begin{tabular}{|c|c|c|c|c|c|c|c|c|c|c|c|c|}
\hline Time Period & \multicolumn{4}{|c|}{$1990-2012$} & \multicolumn{4}{|c|}{$1980-2012$} & \multicolumn{4}{|c|}{$1970-2012$} \\
\hline Variables & Estimate & Std. Error & $\mathrm{z}$ value & $\operatorname{Pr}(>|z|)$ & Estimate & Std. Error & $z$ value & $\operatorname{Pr}(>|z|)$ & Estimate & Std. Error & $z$ value & $\operatorname{Pr}(>|z|)$ \\
\hline Intercept & 6.643 & 2.706 & 2.455 & $0.014 *$ & 0.295 & 0.867 & 0.340 & 0.733 & 0.053 & 0.832 & 0.064 & 0.949 \\
\hline Public Debt/GDP & -0.006 & 0.018 & -0.344 & 0.731 & -0.003 & 0.010 & -0.314 & 0.754 & -0.001 & 0.010 & -0.062 & 0.951 \\
\hline Domestic Debt/Total Public Debt & -2.937 & 1.841 & -1.596 & 0.111 & -0.093 & 0.858 & -0.109 & 0.913 & -0.312 & 0.811 & -0.384 & 0.701 \\
\hline Composite inflation series & 0.020 & 0.082 & 0.250 & 0.803 & 0.045 & 0.016 & 2.716 & $0.007 * *$ & 0.040 & 0.016 & 2.518 & $0.012 *$ \\
\hline External balance on goods and services/GDP & -0.167 & 0.049 & -3.394 & $0.001 * * *$ & -0.092 & 0.027 & -3.395 & $0.001 * * *$ & -0.084 & 0.026 & -3.226 & $0.001 * *$ \\
\hline GDP growth & -0.121 & 0.073 & -1.650 & 0.099 . & -0.103 & 0.034 & -3.017 & $0.003 * *$ & -0.113 & 0.033 & -3.437 & $0.001 * * *$ \\
\hline Inflation & -0.020 & 0.082 & -0.239 & 0.811 & -0.045 & 0.016 & -2.708 & $0.007 * *$ & -0.040 & 0.016 & -2.510 & $0.012 *$ \\
\hline Broad money/GDP & -0.105 & 0.045 & -2.309 & $0.021 *$ & -0.021 & 0.017 & -1.247 & 0.212 & -0.023 & 0.016 & -1.428 & 0.153 \\
\hline Total reserves in months of imports & -0.050 & 0.146 & -0.342 & 0.733 & -0.217 & 0.102 & -2.136 & $0.033 *$ & -0.177 & 0.088 & -2.006 & $0.045 *$ \\
\hline External debt stocks/GNI & -0.082 & 0.034 & -2.424 & $0.015 *$ & 0.013 & 0.011 & 1.160 & 0.246 & 0.010 & 0.011 & 0.862 & 0.388 \\
\hline Domestic credit to private sector/GDP & 0.035 & 0.027 & 1.280 & 0.200 & -0.002 & 0.012 & -0.160 & 0.873 & 0.004 & 0.011 & 0.357 & 0.721 \\
\hline Interest payments on external debt/GNI & 0.424 & 0.364 & 1.164 & 0.244 & -0.305 & 0.128 & -2.384 & $0.017 *$ & -0.273 & 0.125 & -2.186 & $0.029 *$ \\
\hline Debt service & 0.007 & 0.035 & 0.193 & 0.847 & 0.019 & 0.017 & 1.089 & 0.276 & 0.020 & 0.016 & 1.257 & 0.209 \\
\hline Short Term Debt/Total External Debt & -0.197 & 0.060 & -3.264 & $0.001 * *$ & -0.048 & 0.019 & -2.507 & $0.012 *$ & -0.043 & 0.018 & -2.438 & $0.015 *$ \\
\hline Log likelihood & 25.57473 & & & & -63.32550 & & & & -66.79945 & & & \\
\hline LR statistic & 48.75088 & & & & 62.20992 & & & & 59.94329 & & & \\
\hline Prob. (LR statistic) & 0.000005 & & & & 0.000000 & & & & 0.000000 & & & \\
\hline McFadden R-squared & 0.487995 & & & & 0.329395 & & & & 0.309717 & & & \\
\hline Sum squared residual & 6.669642 & & & & 18.83412 & & & & 19.39421 & & & \\
\hline
\end{tabular}

1.The empirical model is equation (8): $Y_{i, t}^{*}=\alpha+\gamma^{\prime} Z_{i, t-1}+\theta^{\prime} D_{i, t-1}+\varepsilon_{i, t} . Y_{i, t}^{*}=1$, if external debt default (or domestic debt default, or banking crisis) erupts; and $Y_{i, t}^{*}=0$, if there's no external debt default (or domestic debt default, or banking crisis). $Z_{i, t-1}$ is a set of macroeconomic variables in i country, at t-1 period. And $D_{i, t-1}$ is a set of debt-related variables in i country, at t-1 period. $\gamma \cdot \theta$ should be estimated. 2 . $^{* * *}, * * *$ Significant at the $0.10,0.05$ and 0.01 , levels, respectively. 
Table 9 Probit Model (Banking crisis Model, Model 3)

\begin{tabular}{|c|c|c|c|c|c|c|c|c|c|c|c|c|}
\hline \multirow{2}{*}{$\begin{array}{c}\text { Time Period } \\
\text { Variables }\end{array}$} & \multicolumn{4}{|c|}{$1990-2008$} & \multicolumn{4}{|c|}{$1980-2008$} & \multicolumn{4}{|c|}{$1970-2008$} \\
\hline & Estimate & Std. Error & $\mathrm{z}$ value & $\operatorname{Pr}(>|z|)$ & Estimate & Std. Error & $z$ value & $\operatorname{Pr}(>|z|)$ & Estimate & Std. Error & $\mathrm{z}$ value & $\operatorname{Pr}(>|z|)$ \\
\hline Intercept & -0.276 & 0.551 & -0.501 & 0.616 & -1.010 & 0.409 & -2.471 & $0.013 *$ & -1.210 & 0.395 & -3.063 & $0.002 * *$ \\
\hline Public Debt/GDP & -0.016 & 0.006 & -2.918 & $0.004 * *$ & -0.011 & 0.004 & -2.813 & $0.005 * *$ & -0.010 & 0.004 & -2.595 & $0.009 * *$ \\
\hline Domestic Debt/Total Public Debt & -0.398 & 0.523 & -0.760 & 0.447 & -0.435 & 0.394 & -1.106 & 0.269 & -0.381 & 0.384 & -0.992 & 0.321 \\
\hline Composite inflation series & 0.008 & 0.015 & 0.529 & 0.597 & 0.008 & 0.011 & 0.719 & 0.472 & 0.007 & 0.011 & 0.664 & 0.506 \\
\hline External balance on goods and services/GDP & 0.036 & 0.012 & 2.993 & $0.003 * *$ & 0.029 & 0.010 & 2.811 & $0.005 * *$ & 0.028 & 0.010 & 2.690 & $0.007 * *$ \\
\hline GDP growth & -0.077 & 0.028 & -2.714 & $0.007 * *$ & -0.051 & 0.019 & -2.742 & $0.006 * *$ & -0.055 & 0.018 & -3.007 & $0.003^{* *}$ \\
\hline Inflation & -0.008 & 0.015 & -0.520 & 0.603 & -0.008 & 0.011 & -0.713 & 0.476 & -0.007 & 0.011 & -0.657 & 0.511 \\
\hline Broad money/GDP & -0.003 & 0.007 & -0.439 & 0.661 & 0.004 & 0.005 & 0.793 & 0.428 & 0.004 & 0.005 & 0.774 & 0.439 \\
\hline Total reserves in months of imports & -0.037 & 0.043 & -0.876 & 0.381 & -0.009 & 0.034 & -0.264 & 0.792 & -0.004 & 0.032 & -0.129 & 0.897 \\
\hline External debt stocks/GNI & 0.006 & 0.007 & 0.827 & 0.408 & 0.010 & 0.005 & 1.973 & $0.048 *$ & 0.010 & 0.005 & 1.979 & $0.048^{*}$ \\
\hline Interest payments on external debt/GNI & 0.283 & 0.116 & 2.437 & $0.015 *$ & 0.116 & 0.059 & 1.957 & 0.050 & 0.136 & 0.059 & 2.322 & $0.020^{*}$ \\
\hline Debt service & 0.006 & 0.013 & 0.505 & 0.613 & 0.006 & 0.009 & 0.610 & 0.542 & 0.005 & 0.009 & 0.646 & 0.518 \\
\hline Short Term Debt/Total External Debt & -0.015 & 0.011 & -1.300 & 0.194 & 0.002 & 0.008 & 0.273 & 0.785 & 0.002 & 0.008 & 0.203 & 0.839 \\
\hline Log likelihood & -147.952 & & & & -223.8574 & & & & 232.7140 & & & \\
\hline LR statistic & 65.92337 & & & & 62.69563 & & & & 71.16892 & & & \\
\hline Prob(LR statistic) & 0.000000 & & & & 0.000000 & & & & 0.000000 & & & \\
\hline McFadden R-squared & 0.182196 & & & & 0.122834 & & & & 0.132630 & & & \\
\hline Sum squared resid & 46.47794 & & & & 70.55385 & & & & 72.03630 & & & \\
\hline
\end{tabular}

1.The empirical model is equation (8): $Y_{i, t}^{*}=\alpha+\gamma^{\prime} Z_{i, t-1}+\theta^{\prime} D_{i, t-1}+\varepsilon_{i, t} . Y_{i, t}^{*}=1$, if external debt default (or domestic debt default, or banking crisis) erupts; and $Y_{i, t}^{*}=0$, if there's no external debt default (or domestic debt default, or banking crisis). $Z_{i, t-1}$ is a set of macroeconomic variables in i country, at t-1 period. And $D_{i, t-1}$ is a set of debt-related variables in i country, at t-1 period. $\gamma, \theta$ should be estimated. $2 . * * * * * *$ Significant at the $0.10,0.05$ and 0.01 , levels, respectively. 
measured through a variety of variables. To the extent that external debt stock is a cause, this would suggest that the large accumulation of external debt by many countries may weigh down by the fiscal stress and speed up the explosion of sovereign default.

\section{Reference}

Abiad, Abdul, 2003," Early Warning System: A Survey and a Regime-Switching Approach," IMF Working Papers 03/32, International Monetary Fund

Breiman, Leo, Jerome H. Friedman ,Charles J. Stone, and R. A. Olshen,1984, "Classification and Regression Trees." Chapman \& Hall. ISBN:0412048418 Subject Headings: CART Algorithm, Gini Index.

Breiman, Leo, 1996, “Bagging Predictors” Machine Learning, 24, 123-140.

Breiman, Leo, 2001, "Random Forests” Machine Learning, 45, 5-32.

Cruces, Juan J. and Christoph Trebesch, 2013,"Sovereign Defaults: The Price of Haircuts," American Economic Journal: Macroeconomics, 5(3), p. 85-117

Chipman, HA, George, EI, and McCulloch, RE, 2010, "BART: Bayesian Additive Regression Trees," Annals of Applied Statistics, 4, p.266-298.

Das, Udaibir, Michael Papaioannou and Christoph Trebesch and, 2012,"Sovereign Debt Restructurings 1950-2010: Literature Survey, Data and Stylized Facts", IMF Working Paper $12 / 203$

Duffie, D., Pedersen, L. and Singleton, K., 2003, "Modeling Sovereign Yield Spreads: A Case Study of Russian Debt”, Journal of Finance, Vol. 58, pp. 119-159

Enderlein, Henrik, Trebesch, Christoph and Laura von Daniels, 2012,"Sovereign Debt Disputes: A Database of Government Coerciveness in Debt Crises, "Journal of International Money and Finance. 31(2), March, P. 250-266

Finger, Harald and Mauro Mecagni, 2007," Sovereign Debt Restructuring and Debt Sustainability : An Analysis of Recent Cross-Country Experience", International Monetary Fund 
Gapen, M., Gray, D., Lim, C. and Xiao, Y., 2005, "Measuring and Analyzing Sovereign Risk with Contingent Claims," IMF Working Paper, 05/155

Gelos, R. Gaston \& Sahay, Ratna \& Sandleris, Guido, 2011. "Sovereign borrowing by developing countries: What determines market access?," Journal of International Economics, Elsevier, vol. 83(2), p.243-254, March.

Manasse, Paolo, and Nouriel Roubini, 2009, "Rules of thumb" for sovereign debt crises", Journal of International Economics, 78(2), P. 192-205

Pescatori, Andrea and Amadou N R Sy, 2007. "Are Debt Crises Adequately Defined?," IMF Staff Papers, Palgrave Macmillan, vol. 54(2), p. 306-337

Reinhart, Carmen M., Kenneth S. Rogoff, and Miguel A. Savastano, 2003, "Debt Intolerance “, Brookings Papers on Economic Activity, (1): p.1-70

Reinhart, Carmen M., and Kenneth S. Rogoff. 2009. This Time Is Different: Eight Centuries of Financial Folly. Princeton, New Jersey: Princeton University Press.

Reinhart, Carmen M. and Kenneth S. Rogoff. 2010. "Growth in a Time of Debt." American Economic Review,100(2), p.573-78.

Reinhart, Carmen M. and Kenneth S. Rogoff, 2011. "From Financial Crash to Debt Crisis," American Economic Review, 101(5), p.1676-1706, August.

Reinhart, Carmen M., Vincent R. Reinhart, and Kenneth S. Rogoff, 2012," Public Debt Overhangs: Advanced Economy Episodes Since 1800," Journal of Economic Perspectives, 26(3), p.69-86

Reinhart, Carmen M. and M Belen Sbrancia, 2015," The liquidation of government debt," Economic Policy, April, p.291-333

Reinhart, Carmen M, Vincent Reinhart, and Kenneth Rogoff, 2015. "Dealing with Debt." Journal of International Economics 96, Supplement 1 (July): S43-S55.

Reinhart, Carmen M. and Christoph Trebesch, 2016," A Distant Mirror of Debt, Default, and Relief"," Journal of the European Economic Association, 14:1

Trevor Hastie, Rob Tibshirani, Jerome Friedman (2009) "Statistical Learning” (Springer). 